\title{
CEO Compensation: Does Financial Crisis Matter?
}

\author{
Prasad Vemala ${ }^{1}$, Lam Nguyen ${ }^{1}$, Dung Nguyen ${ }^{1} \&$ Alekhya Kommasani ${ }^{1}$ \\ ${ }^{1}$ McNeese State University, USA \\ Correspondence: Prasad Vemala, Assistant Professor, College of Business, McNeese State University, Lake \\ Charles, LA-70609, USA. Tel: 1-337-475-5558. E-mail: pvemala@mcneese.edu
}

Received: November 6, 2013

Accepted: February 17, 2014

Online Published: March 26, 2014

doi: $10.5539 /$ ibr.v7n4p125

URL: http://dx.doi.org/10.5539/ibr.v7n4p125

\begin{abstract}
The topic of CEO compensation has been highly debatable. The financial crisis of 2008 further prompted public and media to question executive compensation practices in the United States. This study investigates the effect of the financial crisis on CEO compensation and also examines various determinants of CEO compensation. Using a sample of Fortune 500 firms and 2241 observations, we find that financial crisis has a small but significant effect on CEO compensation. Firm performance, firm size, and CEO duality were found to have a significant effect on CEO compensation both pre and post-crisis. One major difference found between pre and post-crisis was in the composition of pay. While cash compensation decreased significantly post-crisis, equity-compensation increased.
\end{abstract}

Keywords: CEO compensation, financial crisis, firm performance

\section{Introduction}

There is a staunch criticism that CEOs continue to receive higher paychecks at a time when performance of many firms took a dip and many Americans lost their jobs. The criticism became more severe especially due to the economic downturn. The financial crisis of 2008 is considered to be the major crisis occurred after the Great Depression. The crisis resulted in higher unemployment rates, lower GDP growth, and downfall of stock market indices. While many scholars are researching the causes and consequences of financial crisis, few researchers have paid attention to the effect of financial crisis at the firm level, especially on top management such as CEO.

The main goal of this study was to examine the effect of the recent financial crisis on CEO compensation. Further, this paper examined various determinants of CEO compensation both before and after the financial crisis. As existing literature does not provide a concrete set of determinants that affect CEO compensation, this study identified whether commonly evaluated variables such as firm performance, firm size, and corporate governance variables affect CEO pay in the context of the recent financial crisis. While a majority of the firms were affected due to the crisis, it is the large firms that got more attention as they are the main sources of employment and economic growth. Given the criticism from the public and media that CEOs of large firms continue to receive higher pay packages even during the troubled times, it is important to examine whether this is the case.

This study focused on the Fortune 500 firms listed in the year 2008, the year the financial crisis occurred and examined the effect of the financial crisis, firm performance, board quality, and firm size on CEO compensation controlling for CEO characteristics and industry effect. Our results demonstrate that financial crisis has a positive impact on total compensation but has a negative association with cash compensation. Firm performance, firm size, and CEO duality all have significant positive effects on CEO compensation both pre and post-crisis. The paper is organized as follows: Literature Review is discussed next. The third section explains the data used and methodology applied. The fourth section presents results obtained in the study followed by conclusion in the fifth section.

\section{Literature Review}

\subsection{The Context of Financial Crisis}

As the United States is considered as being a country that has strong legal institutions and regulations that strengthen corporate governance of firms, few scholars have predicted the occurrence of the financial crisis that not only shocked the country but also the entire world. Bernanke suggests that subprime losses triggered the 
crisis but does not explain the crisis completely. The main sources of vulnerabilities, according to Bernanke, were shadow banking and short term debt instruments such as repurchase agreements and commercial paper (Gorton \& Metrick, 2012). Many scholars are still examining the causes and consequences of the crisis. Reinhart and Rogoff (2011) in their study suggest that, historically, external debt leads to banking crises and banking crises either precedes or accompanies sovereign debt crisis. Schularick and Taylor (2012) examined the relationship between financial crises and credit growth in the economy for 14 developed countries using a 140-year dataset. They found that an increased credit supply will be followed by a financial crisis. Although these studies have illustrated the causes of the crisis, its consequences were detrimental to businesses on a large scale. Stock market indices such as Dow Jones and S\&P 500 dropped significantly and many firms took a hit on their revenues.

\subsection{CEO Compensation and Firm Performance}

CEO compensation in the U.S. constitutes both cash and equity-based pay, the latter being the major component. While salary could be fixed, equity-based compensation primarily depends on the increased shareholder value. Given the dip in the revenues and stock market value, CEOs' compensation should also take a significant hit. Although some studies could not identify a relationship between firm performance and CEO compensation (e.g., Miller, 1995; Jeppson et al., 2009) many other studies identified a positive relationship between the two (e.g., Jensen \& Murphy, 1990; Cordeiro \& Veliyath, 2003; Hall \& Liebman, 1998; Lilling, 2006; Nourayi \& Daroca, 2008). The results vary depending on the sample and years studied.

\subsection{CEO Compensation and Board Quality}

Since the board plays the role of setting CEO compensation, researchers have also examined the effect of board quality variables such as CEO duality, board size, and board independence on CEO compensation. While some scholars (Gabaix \& Landier, 2008) argue that CEO compensation is determined by the talent, many other studies such as Fama (1980), Jensen (1993), Fama and Jensen (1983), Bebchuk and Fried (2003) advocate that it is the board's decision that determines CEO compensation. When CEO also holds the Chairman position, referred to as CEO duality, agency theory suggests that it might lead to CEO entrenchment and may result in weak monitoring (Finkelstein \& D’Aveni, 1994). Prior empirical studies (e.g., Jensen, 1993; Core et al., 1999; Cyert et al., 2002; Fahlenbrach, 2009) all identified that CEO duality results in higher CEO compensation. Jensen (1993) suggests that small boards improve firm performance and Yermack (1996) empirically identified this. A research study by Core et al. (1999) found that, for every member added on the board, the CEO makes additional $\$ 30,601$ dollars.

\subsection{CEO Compensation and Firm Size}

Firm size is the only factor that a majority of prior research established to be positively associated with CEO compensation. This implies that larger firms pay greater compensation for their CEOs. Ghosh (2006) suggests that large firms constantly look for opportunities to grow and firms recruit CEOs that can do the job. While some studies use firm size as a control variable, others consider it as an explanatory variable. Nourayi and Mintz (2008) and Ghosh (2006) identified a positive effect of firm size on CEO compensation.

From the above literature review, it can be understood that prior researchers examined the effect of firm performance, board variables, and firm size on CEO compensation. However, little research was done to assess the impact of the financial crisis on CEO pay. This study fills the gap by examining how the financial crisis affects CEO compensation for a sample of Fortune 500 firms.

Dodd-Frank Act of 2010 requires that public companies must allow their shareholders to vote on the executive compensation once in every three years. Equilar report of 2011 documented that more than $98 \%$ of the 2,252 Russell 3000 companies received a favorable vote for their existing compensation policies in 2011 . This suggests that shareholders approve CEO compensation practices and CEOs continue to receive higher pay. Faulkender et al. (2010) point out that executive pay in many companies increased even when their stock prices dropped significantly. Based on the above evidence, a positive relationship can be expected between financial crisis and total compensation of CEOs.

H1: Financial crisis will have a positive relationship with CEO total compensation.

The CEO pay-performance relation has been examined extensively and the outcomes have been largely based on the data studied, time period chosen, and variables considered. However, a majority of the studies (e.g., Jensen \& Murphy, 1990; Murphy, 1985; Mehran, 1995; Crawford et al., 1995; Hall \& Liebman, 1998; Lilling, 2006; Kaplan, 2013) have found a positive relationship between CEO pay and firm performance. Prior research in general suggests that firm performance and CEO compensation both move in the same direction. From the above evidence, it can be understood that, irrespective of a financial crisis, firm performance will have a positive 
relationship with CEO compensation.

H2: Firm performance will have a positive relationship with CEO compensation for the firms both before and after financial crisis.

When firms are bigger, CEOs have to put in more effort and have to deal with greater number of complexities and hence deserve to get a higher compensation for the responsibilities. There is substantial evidence in earlier studies that firm size and CEO compensation are positively related (e.g., Finkelstein \& Hambrick, 1989; Lambert et al., 1991; Canarella \& Gasparyan, 2008; Nourayi \& Mintz, 2008). Based on the previous studies, we formulate the following hypothesis.

H3: Firm size will have a positive relationship with CEO compensation for the firms both before and after financial crisis.

One of the main responsibilities of a board chairman is to assess compensation of top management including CEO. If a CEO holds the board chairman position, then he or she can have a greater degree of control on the board. Cyert et al. (2002) found that if CEO is also the board chairman, then he or she receives $36 \%$ higher equity compensation. Fahlenbrach (2009) in a study on the U.S. large firms identified that CEO duality significantly affect pay-for-performance sensitivity. Many studies (e.g., Core et al., 1999; Grinstein et al., 2004) documented that CEO duality results in higher CEO pay. Since a crisis will have no effect on CEO duality, if a $\mathrm{CEO}$ is the chairman, he or she can continue to control the board both pre and post-crisis. Based on the existing evidence, the following hypothesis was formulated.

H4: CEO duality will have a positive relationship with CEO compensation for the firms both before and after financial crisis.

When a board is overcrowded, it does not function effectively and the CEO can easily control the board (Lipton \& Lorsch, 1992; Jensen, 1993). Core et al. (1999) demonstrated that larger boards will result in a higher CEO compensation. Cyert et al. (2002) also found that board size affects compensation significantly and positively. Further, financial crisis is irrelevant in determining the effect of board size and CEO compensation. The following hypothesis was formulated based on the prior evidence.

H5: Board size will have a positive relationship with CEO compensation for the firms both before and after financial crisis.

Some scholars in the past have also examined the relationship between CEO compensation and CEO characteristics such as CEO tenure (e.g., Mangel \& Singh, 1993; Madura et al., 1996), age (e.g., Jalbert et al., 2010), whether the CEO who is also a founder of the company (e.g., Cyert et al., 2002; Jarbert et al., 2010), and gender. The results appear to be mixed in prior empirical studies. We will be using these as control variables in addition to controlling for industry and unemployment variables. The next section explains the data used and methodology.

\section{Data and Methodology}

To examine the effect of the financial crisis and other variables of interest on CEO compensation, Fortune 500 firms which are the largest firms by revenue were considered. Fortune 500 firms that were listed in 2008 were chosen and compensation data for these firms was collected between 2004 and 2012. While the data between 2004 and 2007 illustrates the pre-crisis data, 2009-2012 is considered as being the post crisis data. Although a majority of the firms may remain in the list of fortune firms for a longer period of time, some firms may not make the list in some years. For our study we have considered the firms that made into the Fortune 500 list in all the sample years studied, 2004-2012. We collected CEO compensation data primarily from ExecuComp database and BusinessWeek, Fortune 500 and Forbes were referred in case data was missing. Financial data was collected from Compustat. Since we are going to examine the effect of firm performance on CEO compensation, financial data from the previous year are used for the study. For example, 2003 firm performance data is used with the 2004 compensation figures. Data pertaining to CEO tenure, CEO=Founder, CEO age, CEO gender, Industry, and Unemployment rate were also collected and used as control variables. Whenever the data is unavailable for the variables, the firm was discarded in the sample. As a result of the two conditions, (i) firms should make the Fortune 500 list from 2004-2012 and (ii) data for variables examined should be available for all the years studied, our firm size was reduced to 249. Since we examined 9 years in total, the total sample size was 2241 firm observations. Table 1 below shows descriptive statistics of variables considered in this study for pre-crisis, post-crisis, and full data. 
Table 1. Descriptive statistics

\begin{tabular}{llll}
\hline Variable & $2004-2007$ & $2009-2012$ & $2004-2012$ \\
\hline Total Assets & $16,143,983,094.00$ & $18,487,974,794.00$ & $17,352,636,144.00$ \\
Tobin's Q & 1.31 & 0.93 & 1.13 \\
Stock Price & 44.53 & 33.53 & 39.66 \\
CEO Duality & $64.66 \%$ & $61.85 \%$ & $63.14 \%$ \\
Board Size & 10.82 & 10.89 & 10.86 \\
Tenure & 6.41 & 7.39 & 6.87 \\
Founder & $3.31 \%$ & $2.31 \%$ & $2.77 \%$ \\
Age & 55.67 & 56.65 & 56.10 \\
Gender & $97.89 \%$ & $95.48 \%$ & $96.65 \%$ \\
Cash Compensation & $1,776,709.64$ & $1,066,672.36$ & $1,387,179.41$ \\
Long-term Compensation & $6,792,600.94$ & $7,686,652.84$ & $7,240,841.63$ \\
Total Compensation & $8,569,310.58$ & $8,753,325.20$ & $8,628,021.04$ \\
\hline
\end{tabular}

The descriptive statistics reveal that, while total assets (firm size) and CEO total compensation increase post-crisis, cash compensation and Tobin's Q decrease significantly. The statistics reveal that firms were more profitable before the occurrence of the crisis. Financial crisis did not change any board characteristics as board size and CEO duality approximately remained the same. However, post-crisis, cash compensation decreased by about $40 \%$.

We used pooled time-series cross-sectional regression methodology to study the relationships. Three models were considered in this study. The first two models examined the effect of firm performance, board size, CEO duality, and firm size on CEO compensation pre and post-crisis respectively as shown in equation 1 below. The third model demonstrated the effect of financial crisis on CEO compensation in addition to the other variables examined in Models 1 and 2. Model 3 was examined using equation 2 as shown below. All three models are controlled for $\mathrm{CEO}$ tenure, $\mathrm{CEO}=$ Founder, $\mathrm{CEO}$ age, $\mathrm{CEO}$ gender, Industry, and Unemployment rate.

[1] Total compensation $=\mathrm{f}$ [Firm Performance, Firm Size, CEO Duality, Board Size]

[2] Total compensation $=\mathrm{f}$ [Financial Crisis, Firm Performance, Firm Size, CEO Duality, Board Size]

Total compensation includes short-term compensation such as salary and bonus, and long-term pay including stock options, awards, pension and others. Tobin's Q is a commonly used proxy (Hermalin \& Weisbach, 1991; Yermack, 1996) to measure firm performance and was used in this study. To test the reliability of the results, stock market returns were also used as a proxy for firm performance. Firm size is measured by the total assets. Board size is the number of directors sitting on the board. CEO duality is a dummy variable and is coded as 1 if CEO is also the chairman, otherwise 0 . If CEO is male, the variable is coded as 1 , otherwise 0 . If CEO is also the founder of the company, the variable is coded as 1 , otherwise 0 . CEO tenure is number of years that he or she spent in the current position. A SIC two-digit industry code was used to specify the industry and then industry dummies were created. The Unemployment rate was used to control for the year. Natural logarithm of variables was considered where appropriate. All variables are adjusted for inflation, using 2003 as the base year.

\section{Results}

Regression analysis was performed to examine the hypotheses and the results are provided in the table below, please refer to Table 2. The regression results from Model 3 which includes a complete dataset demonstrate that the financial crisis had a positive association with CEO total compensation as hypothesized in hypothesis 1 . This suggests that CEOs were highly paid even after crisis occurred. However, descriptive statistics help us understand that CEOs took a hit in terms of cash compensation after the crisis occurred but their long-term compensation increased. A regression analysis using cash compensation as dependent variable was performed and it was found that the financial crisis had a significant negative association with CEO cash compensation. The results signify that CEOs were paid highly, but composition of compensation changed as they were paid more in terms of long-term compensation components. 
Table 2. Regression analysis

\begin{tabular}{|c|c|c|c|c|c|c|}
\hline & Model 1 & & Model 2 & & Model 3 & \\
\hline Variable & Coefficient & P-Value & Coefficient & P-Value & Coefficient & P-Value \\
\hline Intercept & 4.22 & $<0.0001 * *$ & 4.41 & $<0.0001 * *$ & 4.02 & $<0.0001 * *$ \\
\hline Financial Crisis & & & & & 0.06 & $0.0016^{* *}$ \\
\hline Tobin's Q & 0.28 & $<0.0001 * *$ & 0.38 & $<0.0001 * *$ & 0.32 & $<0.0001 * *$ \\
\hline Firm Size & 0.32 & $<0.0001 * *$ & 0.24 & $<0.0001^{* *}$ & 0.28 & $<0.0001^{* *}$ \\
\hline CEO Duality & 0.15 & $<0.0001 * *$ & 0.07 & $<0.0001 * *$ & 0.10 & $<0.0001^{* *}$ \\
\hline Board Size & -0.01 & 0.0614 & -0.00 & 0.9713 & -0.00 & 0.0810 \\
\hline Tenure & 0.01 & 0.8552 & 0.06 & $0.0436^{*}$ & 0.03 & 0.1960 \\
\hline Founder & -0.10 & $0.0495^{*}$ & -0.02 & 0.6032 & -0.09 & $0.0057 * *$ \\
\hline Age & -0.00 & 0.1833 & 0.00 & 0.8189 & -0.00 & 0.8266 \\
\hline Gender & -0.07 & 0.2720 & -0.03 & 0.3448 & -0.05 & 0.0919 \\
\hline Unemployment & -0.09 & $<0.0001 * *$ & -0.01 & 0.4151 & -0.00 & 0.3168 \\
\hline I1 & -0.15 & 0.2796 & -0.05 & 0.6180 & -0.09 & 0.2677 \\
\hline I2 & 0.04 & 0.4939 & 0.08 & 0.0599 & 0.07 & $0.0230^{*}$ \\
\hline $\mathrm{I} 3$ & 0.21 & $0.0002 * *$ & -0.00 & 0.9801 & 0.10 & $0.0027^{* *}$ \\
\hline I4 & -0.02 & 0.5066 & -0.09 & $0.0016^{* *}$ & -0.06 & $0.0095^{* *}$ \\
\hline I5 & -0.16 & $<0.0001 * *$ & -0.14 & $<0.0001^{* *}$ & -0.14 & $<0.0001 * *$ \\
\hline I6 & -0.13 & $0.0006^{* *}$ & -0.17 & $<0.0001^{* *}$ & -0.15 & $<0.0001 * *$ \\
\hline I7 & -0.04 & 0.1010 & -0.04 & 0.0779 & -0.04 & $0.0138^{*}$ \\
\hline I8 & -0.11 & $0.0015^{* *}$ & -0.14 & $<0.0001^{* *}$ & -0.14 & $<0.0001^{* *}$ \\
\hline $\mathbf{N}$ & & 996 & & 996 & & 2241 \\
\hline $\operatorname{Adj} R^{2}$ & & 0.29 & & 0.31 & & 0.29 \\
\hline
\end{tabular}

Hypothesis $\mathrm{H} 2$ was well supported as firm performance has a significant positive relationship with CEO total compensation in all three models. This result is consistent with many other prior studies that firm performance plays an important role in determining CEO pay. So, irrespective of financial crisis, firm performance was found to be a major determinant of CEO pay. Firm size also has a significant positive relationship with firm performance in all three models, indicating that larger firms always pay more for their CEOs. This supports our third hypothesis, H3. Board quality variables, CEO duality, and board size were also examined. While CEO duality has a significant positive association with CEO pay, a significant relationship could not be established between board size and pay. $60 \%$ of our sample firms have CEO duality, suggesting that when the CEOs are also assigned the job of chairmanship, they can control their pay and make a hefty paycheck. Overall, our four hypotheses, $\mathrm{H} 1$ to $\mathrm{H} 4$, were supported, but not $\mathrm{H} 5$. The results also revealed that $\mathrm{CEO}$ tenure has a significant effect on CEO pay post-crisis but not pre-crisis. This suggests that number of years served in the position helps a CEO to make more pay after the crisis. Other control variables such as CEO who is also the founder, CEO age, and CEO gender do not seem to affect his or her compensation. Results suggest that transportation, wholesale trade, and finance industries make a higher payment to its CEOs irrespective of the crisis. Results also indicate that CEOs in construction industry receive higher pay checks before the crisis but not the post-crisis. This clearly suggests that CEO pay practices may vary widely from one industry to the other.

\section{Conclusion}

The main idea of this research is to understand whether firms have responded to the constant criticisms by the public about growth in CEO compensation irrespective of the firm performance and economy. To study this, Fortune 500 firms were considered to examine whether financial crisis affects CEO pay and whether the determinants of executive pay have changed due to the occurrence of the crisis. Regressions analyses were 
conducted using pre-crisis, post-crisis, and all data combined. The results were consistent with public and media criticism that CEOs were highly paid even during the crisis times. One interesting result found was that, while long-term compensation increased significantly post-crisis, cash-compensation decreased substantially. The other determinants, firm performance, board size, and CEO duality, all seem to affect CEO compensation, both pre and post-crisis. Although this study examined nine years of data, one limitation was restricting the sample size to Fortune 500 firms. Future research can focus on a larger sample size and also examine why certain industries pay differently to their CEOs when a financial crisis occur. It would be especially interesting to examine the effect of financial crisis on the CEO pay of small firms. The implications of this study should be considered. Although $\mathrm{CEO}$ and board characteristics may vary among firms, firm performance and firm size play a significant role in determining CEO pay.

\section{References}

Bebchuk, L. A., \& Fried, J. M. (2003). Executive compensation as an agency problem. Journal of Economic Perspectives, 17, 71-92. http://dx.doi.org/10.1257/089533003769204362

Canarella, G., \& Gasparyan, A. (2008). New insights into executive compensation and firm performance. Evidence from a panel of "new economy" firms, 1996-2002. Managerial Finance, 34, 537-554. http://dx.doi.org/10.1108/03074350810874064

Cordeiro, J. J., \& Veliyath, R. (2003). Beyond pay for performance: A panel study of the determinants of CEO compensation. American Business Review, 21, 56.

Core, J. E., Holthausen, R. W., \& Larcker, D. F. (1999). Corporate governance, chief executive officer compensation and firm performance. Journal of Financial Economics, 51, 371-406. http://dx.doi.org/10.1016/S0304-405X(98)00058-0

Crawford, A. J., Ezell, J. R., \& Miles, J. R. (1995). Bank CEO pay-performance relations and the effects of deregulation. The Journal of Business, 68, 231-256. http://dx.doi.org/10.1086/296662

Cyert, R., Sok-Hyon, K., \& Kumar, P. (2002). Corporate governance, takeovers and top-management compensation, Theory and evidence. Management Science, 48, 453-469. http://dx.doi.org/10.1287/mnsc.48.4.453.205

Fahlenbrach, R. (2009). Shareholder rights, boards and CEO compensation. Review of Finance, 13, 81-113. http://dx.doi.org/10.1093/rof/rfn011

Fama, E. F. (1980). Agency problems and the theory of the firm. Journal of Political Economy, 88, $288-307$. http://dx.doi.org/10.1086/260866

Fama, E. F., \& Jensen, M. C. (1983). Separation of ownership and control. The Journal of Law and Economics, 26(2), 301-326. http://dx.doi.org/10.1086/467037

Faulkender, M., Kadyrzhanova, D., Prabhala, N., \& Senbet, L. (2010). Executive Compensation: An Overview of Research on Corporate Practices and Proposed Reforms. Journal of Applied Corporate Finance, 22(1), 107-118. http://dx.doi.org/10.1111/j.1745-6622.2010.00266.x

Finkelstein, S., \& D'Aveni, R. A. (1994). CEO duality as a double-edged sword: How boards of directors balance entrenchment avoidance and unity of command. The Academy of Management Journal, 37(5), 1079-1108. http://dx.doi.org/10.2307/256667

Finkelstein, S., \& Hambrick, D. C. (1989). Chief executive compensation: A study of the intersection of markets and political processes. Strategic Management Journal, 10, 121-134. http://dx.doi.org/10.1002/smj.4250100203

Gabaix, X., \& Landier, A. (2008). Why has CEO pay increased so much? The Quarterly Journal of Economics, 123(1), 49-100. http://dx.doi.org/10.1162/qjec.2008.123.1.49

Ghosh, S. (2006). Do board characteristics affect corporate performance? Firm-Level Evidence for India. Applied Economics Letters, 13(7), 435-443. http://dx.doi.org/10.1080/13504850500398617

Gorton, G., \& Metrick, A. (2012). Getting up to speed on the financial crisis: A one-weekend-reader's guide. Journal of Economic Literature, 50(1), 128-150. http://dx.doi.org/10.1257/jel.50.1.128

Grinstein, Y., \& Hribar, P. (2004). CEO compensation and incentives: Evidence from M \& A bonuses. Journal of Financial Economics, 73(1), 119-143. http://dx.doi.org/10.1016/j.jfineco.2003.06.002

Hall, B. J., \& Liebman, J. B. (1998). Are CEOs really paid like bureaucrats? Quarterly Journal of Economics, 


\section{3, 653-692. http://dx.doi.org/10.1162/003355398555702}

Hermalin, B., \& Weisbach, M. (1991). The effects of board composition and direct incentives on firm performance. Financial Management, 20, 101-112. http://dx.doi.org/10.2307/3665716

Jalbert, T., Furumo, K., \& Jalbert, M. (2010). Does educational background affect CEO compensation and firm performance? The Journal of Applied Business Research, 27(1), 15-40.

Jensen, M. (1993). The modern industrial revolution, exit and the failure of internal control systems. Journal of Finance, 48(3), 831-880. http://dx.doi.org/10.1111/j.1540-6261.1993.tb04022.x

Jensen, M. C., \& Murphy, K. J. (1990). Performance pay and top-management incentives. The Journal of Political Economy, 98(2), 225-264. http://dx.doi.org/10.1086/261677

Jeppson, T. C., Smith, W. W., \& Stone, S. R. (2009). CEO compensation and firm performance: Is there any relationship? Journal of Business and Economics Research, 7(11), 81-93.

Kaplan, S. N. (2013). CEO pay and corporate governance in the U.S.: Perceptions, facts, and challenges. Journal of Applied Corporate Finance, 25(2), 8-25. http://dx.doi.org/10.1111/jacf.12013

Lambert, R., Larcker, D., \& Verrecchia, R. (1991). Portfolio considerations in valuing executive compensation. Journal of Accounting Research, 29, 129-149. http://dx.doi.org/10.2307/2491032

Lilling, M. (2006). The link between CEO compensation and firm performance: Does simultaneity matter? Atlantic Economic Journal, International Atlantic Economic Society, 34(1) 101-114.

Lipton, M., \& Lorsch, J. W. (1992). A modest proposal for improved corporate governance. Business Lawyer, 48(1), 59-77.

Madura, J., Martin, A., \& Jessell, K. (1996). Determinants of CEO compensation in small publicly-traded businesses. American Business Review, 14(1), 80-88.

Mangel, R., \& Singh, H. (1993). Ownership structure, board relationships and CEO compensation in large U.S. corporations. Accounting and Business Research, 23(91A), 339-350. http://dx.doi.org/10.1080/00014788.1993.9729902

Mehran, H. (1995). Executive compensation structure, ownership and firm performance. Journal of Financial Economics, 38(2), 163-184. http://dx.doi.org/10.1016/0304-405X(94)00809-F

Miller, D. J. (1995). CEO salary increases may be rational after all: Referents and contracts in CEO pay. Academy of Management Journal, 38(5), 1361-1385. http://dx.doi.org/10.2307/256861

Murphy, K. J. (1985). Corporate performance and managerial remuneration: An empirical analysis. Journal of Accounting and Economics, 7, 11-42. http://dx.doi.org/10.1016/0165-4101(85)90026-6

Nourayi, M. M., \& Daroca, F. P. (2008).CEO compensation, firm performance and operational characteristics. Managerial Finance, 34(8), 562-584. http://dx.doi.org/10.1108/03074350810874082

Nourayi, M. M., \& Mintz, S. M. (2008). Tenure, firm performance and CEOs' compensation. Managerial Finance, 34(8), 524-536. http://dx.doi.org/10.1108/03074350810874055

Reinhart, C. M., \& Rogoff, K. S. (2011). From financial crash to debt crisis. American Economic Review. American Economic Association, 101(5), 1676-1706. http://dx.doi.org/10.1257/aer.101.5.1676

Schularick, M., \& Taylor, A. M. (2012). Credit booms gone bust: Monetary policy, leverage cycles, and financial crises, 1870-2008. American Economic Review, 102(2), 1029-1061. http://dx.doi.org/10.1257/aer.102.2.1029

Yermack, D. (1996). Higher market valuation of companies with a small board of directors. Journal of Financial Economics, 40(2), 185-211. http://dx.doi.org/10.1016/0304-405X(95)00844-5

\section{Copyrights}

Copyright for this article is retained by the author(s), with first publication rights granted to the journal.

This is an open-access article distributed under the terms and conditions of the Creative Commons Attribution license (http://creativecommons.org/licenses/by/3.0/). 